\title{
Sell and Buy Women in Wedding (Changes in the Dowry's Value in Wedding: Ethnographical Study)
}

\author{
Gunawan Widjaja \\ Universitas Krisnadwipayana, Indonesia \\ Corresponding author email: widjaja_gunawan@yahoo.com \\ Firman Wijaya \\ Universitas Krisnadwipayana, Indonesia \\ Corresponding author email: 69firmanwijaya@gmail.com
}

\begin{abstract}
Mahar in Islam is a man's readiness to establish a household towards sakinah, mawaddah, and warahmah. However, along with social changes with higher social strata competition, the dowry value is increasingly tarnished. This research was conducted to see changes in the dowry's value that are not following the purpose of marriage value. This study used a literature review by collecting some literature related to marriage and dowry in Islam. The research results from this study found several findings in the study, including; First, the dowry value following the Shari'a in Islamic teachings by not burdening humans to establish a household has been tainted from the human lifestyle demands. Second, the high dowry value given to men to women is a symbol of social strata for society. Third, the higher the dowry value is given and the higher the view of the community's social strata, the greater the incidence of infidelity, both husband and wife, so that almost the whole world proves that the divorce rate is getting higher.
\end{abstract}

Keywords---islam, mahar, marriage.

\section{Introduction}

Allah created humans in pairs with one another. This pair is a symbol in human life to carry out the routine of daily life until death. However, the creation of humans in pairs has been tarnished by the cultural system adopted by humans. Humans create culture, consisting of clothing, food, shelter, technology, and other cultures, which every day experiences development. The creation of this culture over time experiences a series of different histories with different meanings (Geertz, 1973; Geertz, 1973). This historical sequence describes the changes experienced by humans (Sztompka, 1993) so that it was mapped by Toffler (1980) through three waves, namely agriculture, industry, and the present era, known as the information age (Mujiburrahman, 2017; Aslan \& Hifza, 2020). In the current era or the journey of social change experienced by humans, cultural development has also changed, including the culture of marriage, both from the wedding ceremony system, honesty, terabak nights, and other attempts.

Marriage is legalizing a relationship that was originally haram to become lawful. Legalize this relationship in Islam, a ritual procession of consent, Kabul, and several witnesses are carried out. Humans get married so that establishing a household is a form of maturity between men and women (Lundquist \& Xu, 2014; Nelson \& Otnes, 2005; Prichard \& Tiggemann, 2008; 2014). Of the several marriages carried out by humans, there are two categories: love and doing ta'aruf. These two categories, which humans mostly do in this era to establish a household, are based on love. To establish a household, first make acquaintances; if they feel fit, they will be in a relationship for several months; usually, years and eventually get married and usually break up halfway. Meanwhile, those who do ta'aruf are very rarely done by humans today because ta'aruf is considered no longer suitable for young people today because the ta'aruf system is a feeling of love that only grows marriage. Love is a feeling cultivated by something that makes a person fall in love, so love is often interpreted as a soul and a feeling that every human being cannot control (Langeslag \& Strien, 2016; S. J. Langeslag \& Sanchez, 2018). However, millennials' current generation has

ISSN 2632-9441

Submitted: 09 December 2020 |Revised: 18 January 2021 | Accepted: 27 February 2021 
misinterpreted the meaning of love; millennials have fallen into adultery (Mazurik et al., 2020; Duraku et al., 2020). This is also because humans' technological developments mean that there is no boundary gap between adulthood and adolescence, where teenagers can watch adult shows (Aslan et al., 2019; Aslan, 2017). Then, the influence of peers and the environment experienced by adolescents today, which social changes experienced by humans cause (Walters, 1965; Br Med J., 1967; Bellis et al., 2004; Gündüz-Hoşgör \& Smits, 2008; Neighbors \& Sobal, 2008).

Thus, most of the impact of social change and technological development experienced by humans, the greater the duties, roles, and responsibilities of parents. To prevent their children from taking adverse actions, some parents provide formal education to their children and are successful in pursuing a career in the world. However, when the child is thriving and prosperous in the field of work, the parents' next task is to find a mate for their child. However, children in the present era do not need their parents to find a life partner because a life partner is a life partner based on love. The child's mindset about a mate for himself, which no longer requires his parents' role, also changes his parents' mindset. When the child wants to get married, the parents also determine the dowry paid for by the male party. Each region's dowry culture has different dowries or honesty, both in rural and urban areas.

Due to the impact of social changes experienced by people in various parts of the world, the dowry culture has increased from year to year, including being practiced by Muslims (White, 2017; Makino, 2019; Chowbey, 2017). Some Muslims, when they want to marry off their children, oblige the men to give a high dowry according to the applicable criteria in each region, for example, education, beauty, and other categories which are very contrary to the hadith of the Prophet Muhammad regarding the meaning of a dowry which should not be burdensome men's side. The Hadith of Rasullullah also emphasizes that "the woman who is the most blessed is the woman who is the least dowry."

Thus, the impact of social changes experienced by the community, the dowry or honesty category has begun to conflict with the Islamic religion adhered to so that the term marriage to unite a relationship that is haram to become halal is purchased at such a high cost, that there are indications of buying and selling in marriage.

\section{Research Methods}

This paper wants to reveal this research's analysis to understand the changes in the value of the dowry of marriage, which is believed to be no longer following the guidance of the Islamic religion and the essential value of marriage. This research uses literature study by collecting some literature related to marriage and dowry in Islam. Furthermore, it is examined with a coding system, in-depth evaluation, and interpretation of data before making conclusions about the study's findings, which answer the study questions with validity and high reliability. The data search source is a search using a data-based searching system such as Google Doc, Google Scholar, and other online data-based sources. We chose a descriptive qualitative design in reviewing and reporting the results that were guided by a specialist qualitative data review research (Squires, 2009). In his study "Methodological challenges in cross-language qualitative research: A research review."

\section{Literatur Review}

\section{Wedding and Wedding in Islam}

Marriage is legalizing what is haram to become lawful. To carry out a marriage between a man and a woman for Islam consists of several rituals that are carried out, such as making a proposal or khutbah, and if it is suitable between a man and a woman, then the marriage is carried out. Before carrying out a marriage, there is a sale and purchase or a dowry/honesty set by the woman (Chowdhury et al., 2017). The dowry determined by women for men consists of materials, equipment for women, and other items following the community's existing culture (Aslan \& Yunaldi, 2018). Dowry, or honesty that can no longer be negotiated when it has been agreed upon, is money. The money determined by the woman to the man determines whether or not the marriage will take place. For men who cannot pay honesty to the woman, usually, the marriage will be canceled.

The paradigm of the marriage culture is based on social changes experienced by society so that the suggestion to carry out marriage has undergone extraordinary changes along with human progress. In Islam, a dowry is a form of absolute right for a woman granted to the man. The desire of a man to have a woman and make his wife Islam requires a dowry. Mahar is a symbol of appreciation to care for, respect, and make a woman happy. In language, dowry has an intelligent understanding, which means that a married man feels able to navigate the ark of life (Damis, 2016). Dowry has two categories: dowry in the form of clothes for the wife and other valuable items (Waheed, 2009). The category of dowry change in human life in the event of a marriage cannot be separated from society's 
changes so that the high dowry value has the aim of maintaining a lasting husband and wife relationship and does not occur in divorce (Ambrus et al., 2010). However, the purpose of dowry in Islam contradicts the value of dowry that women require for men, so there are indications that changes in dowry or honesty in community life are influenced by several social, cultural, economic, political, educational, and other factors that conflict with Islamic values.

\section{Research Result}

Change in the dowry of marriage in an Islamic perspective Humans who are old enough and have maturity in thinking is called maturity; they have prepared themselves to find a partner in life or get married. However, for humans who live in the current information era, to carry out a marriage, a dowry or honesty needs to be paid to the woman. The value of this honesty has distinct differences from one region to another, but most see it from children's education, beauty, wealth, and so on.

In Islam, a dowry with a high value is not permitted because the Messenger of Allah in his hadith explains that "the woman who is the most blessed is the woman who is the least dowry." However, along with the changing times in human life with various demands and cultural developments, dowry or honesty has increased. Almost every region has a value from the dowry that is given to women.

The dowry value is higher because of the socioeconomic changes that every human being has (Subhani \& Afza, 2009). The socioeconomic and educational level of women determines the amount of dowry that is given. Most of the eastern Indonesian women's community received a reasonably high dowry from the male side (Kurniawan, 2020). For example, there is unfair treatment for women in India so that when a baby girl is born, it becomes a disgrace for her family. Women who want to get married in India pay high dowries to the men because it is considered (Makino, 2019). This incident illustrates the dowry that experiences differences in each region, where on the one hand, the dowry is burdensome to the family; on the other hand, the dowry symbolizes women's rights, which men must give. In this case, the paradigm difference in understanding the meaning of dowry as a form of women's glory is found in Islam.

Islam, which teaches everything in human life by giving a dowry to the woman according to the man's ability, aims to shape the male personality to be responsible when married. However, fulfilling this responsibility in establishing a household poses a significant obstacle for men. As the parents, Demands wants a high dowry to be given to her child.

Marriage, which is considered essential and is the sunna of the Prophet Muhammad, experiences delays in increasing the value of the dowry set by the woman (Azad \& Sharmin, 2018). Parents' duties and responsibilities by marrying off their children so that the culture of the marriage system hinders their obligations as parents have been resolved in the present era. The higher the parents' rank, dignity, and prestige, the greater the dowry value assigned to other parties.

\section{Conclusion}

Parents' roles, duties, and responsibilities to bring the family from the torment and fire of the country by teaching positive values to their wives and children have changed when social, cultural, economic, and political changes demand family life. Parents want their children to live happily in the world without the afterlife tests, so to get this happiness, some parents are willing to sell their children in marriage with such high tafir value. The higher the dowry value given, the higher the human strata in the view of other humans. A marriage that is not burdensome for the male and determines the dowry according to the male party's ability has experienced a shift, in which the social demands experienced by humans, the value of the dowry has also undergone drastic changes. Marriage to carry out the Shari'a of Allah and the Prophet's sunnah has become an indication of buying and selling marriages that parents have carried out in this era

\section{Acknowledgments}

We are writer thanks colleagues for the advice from the beginning to this paper's writing with all meaningful feedback and input. Likewise for the funds to support the work of this study which was very helpful and so that we were able to complete the implementation of this work with the title "Sell and Buy Women in Wedding (Changes in the Dowry's Value in Wedding: Ethnographical Study)" 


\section{References}

Ambrus, A., Field, E., \& Torero, M. (2010). Muslim family law, prenuptial agreements, and the emergence of dowry in bangladesh. The Quarterly Journal of Economics, 125(3), 1349-1397. JSTOR.

Aslan, A. (2017). Pendidikan remaja dalam keluarga di desa merabuan, kalimantan barat (perspektif pendidikan agama islam). Al-Banjari: Jurnal Ilmiah Ilmu-Ilmu Keislaman, 16(1), 122-135. https://doi.org/10.18592/albanjari.v16i1.1158

Aslan \& Hifza. (2020). The Community Of Temajuk Border Education Values Paradigm On The School. International Journal of Humanities, Religion and Social Science, 4(1), 13-20.

Aslan, Setiawan, A., \& Hifza. (2019). Peran Pendidikan dalam Merubah Karakter Masyarakat Dampak Akulturasi Budaya di Temajuk. Fenomena, 11(1), 11-30. https://doi.org/10.21093/fj.v11i1.1713

Aslan, \& Yunaldi, A. (2018). Budaya berbalas pantun sebagai media penyampaian pesan perkawinan dalam acara adat istiadat perkawinan melayu sambas. jurnal transformatif (islamic studies), 2(2), 111-122. https://doi.org/10.23971/tf.v2i2.962

Azad, M. M., \& Sharmin, S. S. (2018). Laws of Muslim Marriage from the concept of the Holy Qur'an. ResearchGate.

https:/www.researchgate.net/publication/326982042_Laws_of_Muslim_Marriage_from_the_concept_of_the_Ho ly_Qur\%27an

Bellis, M. A., Hughes, K., \& Ashton, J. R. (2004). The promiscuous 10\%? Journal of Epidemiology \& Community Health, 58(11), 889-890. https://doi.org/10.1136/jech.2004.027847

Br Med J. (1967). Sexual promiscuity among students. British Medical Journal, 1(5542), 711-712.

Chowbey, P. (2017). Women's narratives of economic abuse and financial strategies in Britain and South Asia. Psychology of Violence, 7(3), 459.

Chowdhury, S., Mallick, D., \& Chowdhury, P. R. (2017). Natural Shocks and Marriage Markets: Evolution of Mehr and Dowry in Muslim Marriages (SSRN Scholarly Paper ID 2949111). Social Science Research Network. https://papers.ssrn.com/abstract=2949111

Damis, H. (2016). Konsep mahar dalam perspektif fikih dan perundang-undangan. Jurnal Yudisial, 9(1), 19-35. https://doi.org/10.29123/jy.v9i1.29

Duraku, Z. H., Jemini-Gashi, L., \& Toçi, E. (2020). Perceptions of Early Marriage, Educational Aspirations, and Career Goals among Kosovar Adolescents. Marriage \& Family Review, 56(6), 513-534. https://doi.org/10.1080/01494929.2020.1728006

Gündüz-Hoşgör, A., \& Smits, J. (2008, March). Variation in labor market participation of married women in Turkey. In Women's Studies International Forum (Vol. 31, No. 2, pp. 104-117). Pergamon. https://doi.org/10.1016/j.wsif.2008.03.003

Geertz, C. (1973). The Interpretation Of Cultures. Basic Books, Inc., Publisher.

Kurniawan, R. (2020). Determinants of the dowry: finding from ifls east. jurnal dinamika ekonomi pembangunan, 2(2), 71-79. https://doi.org/10.14710/jdep.2.2.71-79

Langeslag, S. J. E., \& Strien, J. W. van. (2016). Regulation of Romantic Love Feelings: Preconceptions, Strategies, and Feasibility. PLOS ONE, 11(8), e0161087. https://doi.org/10.1371/journal.pone.0161087

Langeslag, S. J., \& Sanchez, M. E. (2018). Down-regulation of love feelings after a romantic break-up: Self-report and electrophysiological data. Journal of Experimental Psychology: General, 147(5), 720.

Lundquist, J., \& Xu, Z. (2014). Reinstitutionalizing Families: Life Course Policy and Marriage in the Military. Journal of Marriage and Family, 76(5), 1063-1081. https://doi.org/10.1111/jomf.12131

Makino, M. (2019). Marriage, dowry, and women's status in rural Punjab, Pakistan. Journal of Population Economics, 32(3), 769-797. https://doi.org/10.1007/s00148-018-0713-0

Mazurik, K., Knudson, S., \& Tanaka, Y. (2020). Stuck in the Nest? A Review of the Literature on Coresidence in Canada and the United States. Marriage \& Family Review, 56(6), 491-512. https://doi.org/10.1080/01494929.2020.1728005

Mujiburrahman. (2017). Agama Generasi Elektronik (Cetakan Pertama). Pustaka Pelajar.

Squires, A. (2009). Methodological challenges in cross-language qualitative research: A research review.

Neighbors, L. A., \& Sobal, J. (2008). Weight and weddings: Women's weight ideals and weight management behaviors for their wedding day. Appetite, 50(2-3), 550-554. https://doi.org/10.1016/j.appet.2007.11.001

Nelson, M. R., \& Otnes, C. C. (2005). Exploring cross-cultural ambivalence: a netnography of intercultural wedding message boards. Journal of Business Research, 58(1), 89-95. https://doi.org/10.1016/S0148-2963(02)00477-0

International Journal of Nursing Studies, 46(2), 277-287. 
Prichard, I., \& Tiggemann, M. (2008). An examination of pre-wedding body image concerns in brides and bridesmaids. Body Image, 5(4), 395-398. https://doi.org/10.1016/j.bodyim.2008.05.001

Prichard, I., \& Tiggemann, M. (2014). Wedding-related weight change: The ups and downs of love. Body image, 11(2), 179-182. https://doi.org/10.1016/j.bodyim.2013.12.005

Subhani, M. I., \& Afza, S. (2009). To estimate an equation explaining the determinants of Dowry [MPRA Paper]. https://mpra.ub.uni-muenchen.de/21365/

Sztompka, P. (1993). Sociology Of Social Change. Oxford UK.

Toffler, A. (1980). The Third Wave. William Morrow and Company, INC.

Waheed, A. (2009). Dowry among Indian Muslims: Ideals and Practices. Indian Journal of Gender Studies. https://doi.org/10.1177/097152150801600103

Walters, P. A. (1965). Promiscuity in Adolescence*. American Journal of Orthopsychiatry, 35(4), 670-675. https://doi.org/10.1111/j.1939-0025.1965.tb00436.x

White, S. C. (2017). Patriarchal Investments: Marriage, Dowry and the Political Economy of Development in Bangladesh. Journal of Contemporary Asia, 47(2), 247-272. https://doi.org/10.1080/00472336.2016.1239271 